AGREGAT: Jurnal Ekonomi dan Bisnis

Vol. 1, No. 1, Maret 2017

http://journal.uhamka.ac.id/index.php/agregat

p-ISSN: 2549-5658 e-ISSN: 2549-7243

DOI: $10.22236 /$ agregat_vol1/is1pp20-37

Hal 20-37

\title{
MUTASI TERHADAP KINERJA KARYAWAN PADA PT KERETA API INDONESIA (PERSERO) DAERAH OPERASI 1 JAKARTA
}

\author{
Ferdian Erlangga Rosa \\ Ikatan Sarjana Ekonomi Indonesia \\ Email: ferdian@gmail.com \\ Diterima: 3 Januari 2017; Direvisi: 7 Februari 2017; Disetujui: 25 Februari 2017
}

\begin{abstract}
This study aims to determine the effect of the mutation on the performance of employees at PT Kereta Api Indonesia (Persero) Regional Operations 1 Jakarta. In this study using survey methods and eksplansi with the collection directly from the original source, in the form of questionnaires were drawn from a sample. The sample in this study were all employees of PT Kereta Api Indonesia (Persero) Jakarta Regional Operations 1102 respondents. Data analysis and processing techniques used are validity, reliability test, descriptive analysis, simple linear regression analysis. Based on the results of data processing test " $t$ " to see the effect of the mutation on employee performance variables significant or not, it can be seen from the figures the probability (sig). Probability value $0.000<0.05$ by $t$ value $=6.305$ and t table $=1.66023 .1 .66023$ Figures obtained from the t table with $\alpha=0.05$ and degrees of freedom (df) $n k-1=100$. If $t>t$ table is 6.305> 1.66023, so it can be concluded that Ho is rejected or mutations significantly influence employee performance.
\end{abstract}

Keywords: Mutations, Employee Performance

\begin{abstract}
Abstrak
Penelitian ini bertujuan untuk mengetahui pengaruh mutasi terhadap kinerja karyawan pada PT Kereta Api Indonesia (Persero) Daerah Operasi 1 Jakarta. Dalam penelitian ini menggunakan metode survey dan eksplansi dengan pengumpulan secara langsung dari sumber asli, berupa penyebaran kuesioner yang diambil dari suatu sampel. Sampel dalam penelitian ini adalah seluruh karyawan PT Kereta Api Indonesia (Persero) Daerah Operasi 1 Jakarta sebanyak 102 responden. Teknik pengolahan dan analisis data yang digunakan adalah uji validitas, uji reliabilitas, analisis deskriptif, analisis regresi linier sederhana. Berdasarkan dari hasil pengolahan data uji " $t$ " untuk melihat pengaruh variabel mutasi terhadap kinerja karyawan signifikan atau tidak, dapat dilihat dari angka probabilitas (sig). Nilai probabilitas 0,000 $<0,05$ dengan nilai t hitung $=6,305$ dan $t$ tabel $=1,66023$. Angka 1,66023 diperoleh dari t tabel dengan $\alpha=0,05$ dan derajat kebebasan (df) $n-k-1=$ 100. Jika t hitung $>\mathrm{t}$ tabel yaitu 6,305 $>1,66023$, sehingga dapat disimpulkan bahwa Ho ditolak atau mutasi berpengaruh signifikan terhadap kinerja karyawan.
\end{abstract}

Kata Kunci: Mutasi, Kinerja Karyawan. 


\section{PENDAHULUAN}

Sumber daya manusia merupakan sumber daya yang paling penting di perusahaan. Sebagai aset perusahaan yang sangat berharga, maka penting bagi perusahaan untuk selalu membina dan mengembangkan potensi dari sumber daya manusia yang dimilikinya. Salah satu usaha yang dilakukan adalah dengan penerapan mutasi. Program ini diharapkan dapat menjamin kualitas sumber daya manusia yang dimiliki oleh perusahaan dan pemanfaatannya yang optimal, karena secanggih apapun peralatan yang dimiliki oleh perusahaan tidak akan ada artinya jika tidak di dukung oleh sumber daya manusia yang terampil dan memiliki kinerja yang tinggi.

Melalui manajemen sumber daya manusia, perusahaan dapat mengambil langkah-langkah yang akan membantu memenuhi keinginan dan kebutuhan karyawan sesuai dengan kemampuan para karyawannya. Dengan kondisi tersebut diharapkan karyawan dapat memiliki perilaku dan kinerja yang baik dalam melaksanakan pekerjaannya sebagai penunjang upaya mencapai tujuan. Mutasi selain dapat meningkatkan kinerja, dapat pula memberikan kesempatan kepada karyawan untuk mengembangkan potensi yang dimilikinya.
Mutasi pada dasarnya adalah pemindahan karyawan dari suatu jabatan ke jabatan yang lain yang sifatnya sejajar. Tetapi masyarakat sering mengartikan bahwa karyawan yang di mutasi adalah karyawan yang di hukum karena melakukan kesalahan atau menyalah gunakan kedudukannya. Tetapi perlu diingat bahwa mutasi sebenarnya dilakukan untuk melakukan penyegaran, sehingga tidak menimbulkan kejenuhan dalam melaksanakan suatu pekerjaan.

PT Kereta Api Indonesia (Persero) merupakan salah satu Badan Usaha Milik Negara yang bergerak di bidang jasa transportasi perkeretaapian terbesar di Indonesia. PT Kereta Api Indonesia (Persero) sebagai induk perusahaan membawahi sembilan daerah operasi dan tiga divisi regional, salah satunya adalah daerah operasi 1 Jakarta atau biasa disingkat DAOP 1 Jakarta. PT Kereta Api Indonesia (Persero) DAOP 1 Jakarta bisa dibilang merupakan daerah operasi yang memiliki aktivitas terpadat, karena daerah operasi 1 Jakarta selain melayani rute perjalanan jarak jauh, juga melayani rute perjalanan Jabodetabek dengan menggunakan armada kereta listrik (KRL). Dengan budaya perusahaan yang selalu menjunjung tinggi integritas, 
profesional, keselamatan, inovasi dan pelayanan prima, insan perkeretaapian Indonesia dituntut untuk selalu memberikan yang terbaik kepada konsumen.

Kebijakan pengembangan karir yang dilakukan oleh PT Kereta Api Indonesia (Persero) yaitu dengan mengadakan program pendidikan, pelatihan, mutasi serta promosi jabatan. Mutasi dan rotasi merupakan fenomena yang biasa terjadi di perusahaan. Dengan adanya mutasi diharapkan dapat meningkatkan kinerja karyawan dan sebagai pendorong agar motivasi kerja karyawan meningkat dan untuk menghilangkan rasa bosan atau jenuh terhadap pekerjaannya agar dapat tercipta penyegaran terhadap karyawan dan penyegaran terhadap organisasi. Selain itu untuk memenuhi keinginan karyawan sesuai dengan minat dan bidang tugasnya masing-masing dimana dalam kegiatan pelaksanaan mutasi kerja sering disalah artikan orang yaitu sebagai hukuman jabatan atau didasari atas hubungan baik antara atasan dengan bawahan. Bagi karyawan kereta api terdapat ketentuan tentang perpindahan karyawan, seperti yang diatur dalam perjanjian kerja bersama PT Kereta Api Indonesia (Persero) dengan Serikat
Pekerja Kereta Api (SPKA) pasal 15 tentang pengangkatan dan mutasi jabatan. Dalam pelaksanaan mutasi harus benarbenar berdasarkan penilaian yang objektif dan didasarkan atas prestasi yang dicapai oleh karyawan mengingat pemberian mutasi dimaksudkan untuk memberikan peluang bagi para karyawan kereta api untuk mengembangkan potensi yang dimilikinya. Dengan adanya mutasi yang dilakukan oleh perusahaan akan membuat pimpinan mudah sekali mengetahui tingkat kemampuan yang mendukung kualitas dan kuantitas kerja karyawan.

Penelitian terdahulu yang pertama Mohammad Khalaj Ghasem Abadi (2013), Islamic Azad University, IRAN. Melakukan penelitian dengan judul: Effect of Job Mutation on Employee Performance in Irancell Company. Penelitian terdahulu yang kedua diperoleh dari jurnal yang dibuat oleh Riana Widianti (2014), Universitas Pendidikan Indonesia. Melakukan penelitian dengan judul "Pengaruh Mutasi Personal Terhadap Kinerja Pegawai di Badan Pemberdayaan Perempuan, Perlindungan Anak, Pengendalian Kependudukan, dan Keluarga Berencana (BP3APKKB) Provinsi Jawa Barat”. Penelitian terdahulu yang ketiga dari jurnal yang dibuat oleh 
22 AGREGAT: Jurnal Ekonomi dan Bisnis

Vol. 1 No 1 Maret 2017

http://journal.uhamka.ac.id/index.php/agregat

DOI: 10.22236/agregat_vol1/is1pp20-37

Dwi Ade Putra (2010), Universitas Islam

Riau. Dengan judul: Pengaruh Mutasi

Kerja Terhadap Kinerja Pegawai Pada

Dinas Perindustrian dan Perdagangan

Provinsi Riau.

Dalam beberapa literatur dijelaskan pengertian mutasi seperti pengertian mutasi menurut Dessler (2007) Perpindahan kerja atau mutasi adalah perpindahan pegawai dari satu pekerjaan ke pekerjaan lain pada level yang sama dan pada tingkat upah atau gaji yang sama pula. Tidak ada peningkatan atau penurunan tanggung jawab, walaupun mungkin ada perubahan dalam kondisi kerjanya.

"Job transfer is the transfer process of an employee from one job to other work at the same level and at the level of wages or salaries same anyway. No increase or decrease in responsibility, although there may be changes in working conditions."

Menurut Sastrohadiwiryo (2003) menyatakan mutasi adalah kegiatan ketenagakerjaan yang berhubungan dengan proses pemindahan fungsi, tanggung jawab, dan status ketenagakerjaan tenaga kerja ke situasi tertentu dengan tujuan agar tenaga kerja yang bersangkutan memperoleh kepuasan kerja yang mendalam dan dapat memberikan prestasi kerja yang semaksimal mungkin kepada organisasi.
Menurut Hasibuan (2009) mutasi adalah suatu perubahan posisi/jabatan / tempat / pekerjaan yang dilakukan baik secara horizontal maupun vertikal (promosi/demosi) di dalam satu organisasi. Pada dasarnya mutasi termasuk dalam fungsi pengembangan pegawai, karena tujuannya adalah untuk meningkatkan efisiensi dan efektivitas kerja dalam organisasi tersebut.

Siagian (2008) mengemukakan bahwa mutasi tersebut dengan istilah alih tugas dan alih tempat, yaitu sebagai berikut: Alih tugas adalah penempatan seorang pegawai pada tugas baru dengan tanggung jawab, hierarki jabatan, dan penghasilan yang relatif sama dengan statusnya yang lama. Dalam hal demikian seorang pegawai ditempatkan pada satuan kerja baru yang lain dari satuan kerja dimana seseorang selama ini bekerja. Sedangkan alih tempat, adalah seorang pegawai melakukan pekerjaan yang sama atau sejenis, penghasilan tidak berubah dan tanggung jawabnya pun relatif sama. Hanya saja secara fisik lokasi tempatnya bekerja lain dari yang sekarang.

Selanjutnya, Rivai

mengemukakan istilah mutasi dengan transfer, yaitu sebagai berikut: transfer terjadi kalau seorang karyawan 
dipindahkan dari suatu bidang tugas ke bidang tugas lainnya yang tingkatannya hampir sama baik tingkat gaji, tanggung jawab, maupun tingkat strukturalnya.

Berdasarkan keterangan dari para ahli diatas dapat disimpulkan bahwa mutasi merupakan proses pemindahan fungsi, tanggung jawab, serta status kepegawaian yang bersangkutan dengan tujuan agar pegawai tersebut mendapatkan kepuasan dalam kerja serta berprestasi secara maksimal bagi organisasi. Disamping itu, suatu jabatan/pekerjaan dilakukan terlalu lama mungkin dapat menimbulkan kebosanan dengan segala akibatnya.

Menurut Bernardian, John H \& Joyje E.A Russel (1993) yang dikutip Sedarmayanti (2004) menyatakan bahwa:

"Performance is defined as the record of outcomes produced or a specific job function or activity during, a specific time period."

Yakni kinerja di definisikan sebagai catatan mengenai outcome yang dihasilkan dari suatu aktivitas tertentu, selama kurun waktu tertentu pula. Pendapat lain mengutarakan bahwa kinerja adalah terjemahan dari "performance", berarti: perbuatan, pelaksanaan pekerjaan prestasi kerja, pelaksanaan pekerjaan yang berdaya guna.

Menurut Veithzal Rivai (2010) dalam bukunya menjelaskan bahwa kinerja merupakan suatu fungsi dari motivasi dan kemampuanuntuk menyelesaikan tugas atau pekerjaan seseorang sepatutnya memiliki derajat kesediaan dan tingkat kemampuan tertentu. Kesediaan dan keterampilan tertentu. Kesediaan dan keterampilan seseorang tidaklah cukup efektif utuk mengerjakan sesuatu tanpa pemahaman yang jelas tentang apa yang akan dikerjakan dan bagaimana mengerjakannya. Kinerja merupakan prilaku nyata yang ditampilkan setiap orang sebagai prestasi kerja yang dihasilkan oleh karyawan sesuai dengan perannya dalam perusahaan.Kinerja karyawan merupakan suatu hal yang sangat penting dalam upaya perusahaan untuk mencapai tujuan.

Pengertian kinerja karyawan menurut Anwar Prabu Mangkunegara (2011) bahwa Kinerja karyawan (prestasi kerja) adalah hasil kerja secara kualitas dan kuantitas yang dicapai oleh seseorang karyawan dalam melaksanakan tugasnya sesuai dengan tanggung jawab yang diberikan kepadanya.

Menurut Moeheriono (2009), pengertian kinerja (performance) merupakan gambaran mengenai tingkat pencapaian pelaksanaan suatu program kegiatan atau kebijakan dalam 
24 AGREGAT: Jurnal Ekonomi dan Bisnis

Vol. 1 No 1 Maret 2017

http://journal.uhamka.ac.id/index.php/agregat

DOI: 10.22236/agregat_vol1/is1pp20-37

mewujudkan sasaran,tujuan, visi dan misi organisasi yang dituangkan melalui perencanaan strategis suatu organisasi.

Menurut Jumingan

menjelaskan pengertian tentang kinerja sebagai berikut: "Kinerja merupakan gambaran prestasi yang dicapai perusahaan dalam kegiatan operasionalnya baik menyangkut aspek kuangan, aspek pemasaran, aspek penghimpunan dana dan penyaluran dana, aspek teknologi, maupun aspek sumber daya manusianya”.

Berdasarkan kelima teori diatas dapat disimpulkan bahwa kinerja merupakan hasil kerja secara kualitas dan kuantitas yang dicapai oleh seseorang karyawan dalam melaksanakan tugasnya sesuai dengan tanggung jawab yang diberikan kepadanya.

Dalam suatu organisasi atau perusahaan, sumber daya manusia dalam hal ini adalah para karyawan yang memiliki peran yang penting dalam meningkatkan kinerja untuk diperlukan kinerja yang baik dan organisasi dapat memperbaiki hal tersebut dengan memperbaiki pelaksaan mutasi kerja yang sesuai dengan kebutuhan oleh karyawan untuk melayani pelanggan.
Para pegawai akan lebih termotivasi untuk melakukan tanggung jawab atas pekerjaan apabila perusahaan mengerti dan memperhatikan betul akan kebutuhan para pegawai yang pada dasarnya mereka yang bekerja untuk mendapatkan penghasilan.

Bagi organisasi atau perusahaan, penelitian kinerja sangat berguna untukmenilai kualitas, kuantitas, ketrampilan, sikap, dan perilaku kerja para karyawan serta melakukan pengawasan dan perbaikan. Terpenuhinya mutasi kerja yang baik akan meningkatkan kinerja karyawan, untuk mengukur kinerja yang baik melalui penilai kinerja dan hasil tersebut organisasi dapat menemukan karyawan yang berkualitas dan profesional dalam bekerja.

Kinerja pegawai sangat tergantung dari prestasi kerja, besar kecilnya pengaruh tersebut tergantung pada bagaimana perusahaan tersebut dalam mengorganisir sumberdaya manusia sebagian besar tergantung kualitas, ketrampilan karyawan serta sikap dan perilaku, maka kinerja karyawan lebih besar pengaruhnya dari teknologi. Oleh karena itu salah satu cara terbaik untuk mengikatkan kinerja karyawan adalah 
dengan menghubungkan pelaksanaan mutasi dengan kinerja karyawan.

PT Kereta Api Indonesia (Persero) sangat menyadari betapa pentingnya skill, wawasan serta pengetahuan bagi karyawan. Hal ini diharapkan dapat memberikan motivasi bagi pegawai untuk bekerja secara maksimal.

\section{METODE PENELITIAN}

Pengertian metode penelitian menurut Sugiyono (2012) adalah cara ilmiah untuk mendapatkan data yang valid dengan tujuan dapat ditemukan, dibuktikan, dikembangkan suatu pengetahuan tertentu sehingga pada gilirannya dapat digunakan untuk memahami, memecahkan dan mengantisipasi masalah.

Menurut Sugiyono (2008) menjelaskan bahwa metode survey adalah metode penelitian yang dilakukan pada populasi besar maupun kecil, tetapi data yang dipelajari adalah data dari sampel yang diambil dari populasi.

Dalam penelitian ini digunakan metode survey karena penelitian ini menggunakan data yang diperoleh dari sampel karyawan PT Kereta Api Indonesia (Persero) Daerah Operasi 1 Jakarta.

Populasi dalam penelitian ini adalah karyawan PT Kereta Api Indonesia (Persero) Daerah Operasi 1 Jakarta dengan jumlah karyawan 137 orang. Penentuan besarnya sampel sangat penting karena mewakili populasi penelitian, oleh karena itu pengambilan jumlah sampel dapat digunakan rumus Slovin adalah $\mathrm{n}=$ 102.04. Dari hasil perhitungan diatas maka sampel yang akan diambil setelah melalui pembulatan adalah sebanyak 102 orang responden.

Tempat penelitian dilaksanakan di PT Kereta Api Indonesia (Persero) berlokasi di Jl. Cikini Raya, Cikini, Menteng, Jakarta Pusat.Adapun waktu penelitian dilaksanakan selama 2 bulan terhitung bulan Juni sampai Agustus 2015.

Dalam penelitian ini menggunakan metode kuisioner dalam pengumpulan data yang mengacu pada system skala likert digunakan untuk mengukur sikap seseorang tentang objek sikap. Objek sikap ini biasanya telah ditentukan secara spesifik dan sistematis oleh periset. Indikator-indikator dari variabel sikap terhadap suatu objek merupakan titik tolak dalam membuat pertanyaan atau pernyataan tersebut dihubungkan dengan jawaban yang berupa dukungan atau sikap yang diungkapkan dengan kata-kata "sangat setuju” (SS), "setuju” (S), "raguragu” (RR), “tidak Setuju” (TS), “sangat tidak setuju” (STS). 
26 AGREGAT: Jurnal Ekonomi dan Bisnis

Vol. 1 No 1 Maret 2017

http://journal.uhamka.ac.id/index.php/agregat

DOI: 10.22236/agregat_vol1/is1pp20-37

Uji Validitas digunakan untuk mengukur sah atau tidaknya suatu kuesioner. Suatu kuesioner dikatakan valid jika pertanyaan pada kuesioner mampu untuk mengungkapkan suatu yang akan diukur oleh kuesioner tersebut. Untuk menguji apakah masing-masing indikator valid atau tidak, dapat dilihat dari tampilan output Cronbach Alpha pada kolom Correlation dengan perhitungan ftabel. Jika $r$ hitung lebih besar dari $r$ tabel dengan nilai positif maka butir pertanyaan atau indikator tersebut dinyatakan valid (Ghozali 2005).

Menurut Ghozali (2009) reliabilitas adalah tingkat kepercayaan hasil suatu pengukuran yang memiliki reliabilitas tinggi yaitu pengaruh yang mampu memberikan hasil ukur yang terpercaya. Reliabilitas merupakan salah satu ciri atau karakter utama instrumen pengaruh yang baik. Berdasarkan hal tersebut, maka setelah melakukan pengujian validitas, langkah selanjutnya adalah melakukan pengujian reliabilitas untuk menguji kecenderungan atau kepercayaan alat pengukuran dengan diperoleh nilai $\mathrm{r}$ dari pengujian realibilitas yang menunjukan hasil indeks korelasi yang menyatakan ada tidaknya hubungan antara dua belah instrumen. Uji reliabilitas bertujuan untuk mengukur konsistensi indikator (variabel) penelitian. Suatu kuesioner dikatakan reliabel jika jawaban seseorang terhadap pernyataan adalah konsisten atau stabil dari waktu ke waktu. Untuk menguji keandalan kuesioner yang digunakan, maka dilakukan analisis reliabilitas berdasarkan koefisien Alpha Cronbach. Alpha Cronbach menafsirkan korelasi antara skala yang dibuat dengan semua skala indikator yang ada dengan keyakinan tingkat kendala. Indikator yang dapat diterima apabila koefisien alpha diatas 0,60 suatu konstruk atau variabel dikatakan reliabel jika memberikan nilai Alpha Cronbach> 0,60.

Menurut Sugiyono (2007) Statistik deskriptif adalah statistik yang digunakan untuk menganalisa data dengan cara mendeskriptifkan atau menggambarkan data yang telah terkumpul sebagaimana adanya tanpa bermaksud membuat kesimpulan yang berlaku untuk umum atau generalisasi. Statistik deskriptif biasa digunakan untuk mendeskripsikan demografi responden diantaranya yaitu usia, jenis kelamin, pekerjaan, pendapatan, dan lain-lain.

Mengingat metode analisis yang digunakan adalah analisis regresi linier berganda dan data penelitian yang 
digunakan adalah data sekunder, maka untuk memenuhi syarat yang ditentukan sehingga penggunaan regresi linier berganda perlu dilakukan pengujian atas beberapa asumsi klasik yang digunakan untuk penelitian ini yaitu diantaranya uji normalitas, uji multikolinearitas,uji heteroskedastisitas dan uji autokorelasi.

\section{HASIL PENELITIAN DAN PEMBAHASAN}

Berikut ini akan kita lihat hasil penelitian:

Tabel 1

Indikator Mutasi (X)

\begin{tabular}{|l|l|l|l|}
\hline No. & Per nyataan & $\begin{array}{l}\text { Jumlah Jawaban } \\
\text { Responden }\end{array}$ & Rata-rata \\
\hline 1 & $\begin{array}{l}\text { Saya merasa suasana lingkungan kerja di } \\
\text { perusahaan dapat meningkatkan semangat } \\
\text { kerja saya. }\end{array}$ & 449 & 4.40 \\
\hline 2 & $\begin{array}{l}\text { Saya merasa fasilitas kantor yang ada } \\
\text { diperusahaan sangat mendukung pekerjaan } \\
\text { saya. }\end{array}$ & 451 & 4.42 \\
\hline 3 & $\begin{array}{l}\text { Saya senantiasa menciptakan suasana kerja } \\
\text { yang baik. }\end{array}$ & 462 & 4.52 \\
\hline 4 & $\begin{array}{l}\text { Saya merasa jabatan yang diberikan } \\
\text { perusahaan telah sesuai dengan prestasi } \\
\text { saya. }\end{array}$ & 479 & 4.69 \\
\hline 5 & $\begin{array}{l}\text { Saya mampu mengemban jabatan yang } \\
\text { diberikan oleh perusahaan. }\end{array}$ & 458 & 4.39 \\
\hline 6 & $\begin{array}{l}\text { Saya merasa pekerjaan yang diberikan telah } \\
\text { sesuai dengan kemampuan saya. }\end{array}$ & 448 & 4.57 \\
\hline 7 & $\begin{array}{l}\text { Saya bekerja dengan sangat baik sehingga } \\
\text { kompensasi yang diberikan sesuai dengan } \\
\text { apa saya kerjakan. }\end{array}$ & 467 & 4.73 \\
\hline 8 & $\begin{array}{l}\text { Saya selalu memanfaatkan waktu bekerja } \\
\text { dengan baik. }\end{array}$ & 483 & 4.52 \\
\hline 9 & $\begin{array}{l}\text { Saya dapat menjalankan tugas yang baru } \\
\text { sesuai dengan tanggung jawab. }\end{array}$ & 462 & 4.54 \\
\hline 10 & $\begin{array}{l}\text { Saya memiliki semangat yang tinggi di } \\
\text { dalam bekerja. }\end{array}$ & 479 & 499 \\
\hline Rata-rata & Sa & 4.39 \\
\hline
\end{tabular}

Sumber : PT Kereta Api Indonesia (Persero) Daerah Operasi 1 Jakarta

Dari tabel 1 dapat dilihat poin tertinggi pernyataan "Saya selalu memanfaatkan atau kekuatan relatif pada indikator waktu bekerja dengan baik”. Poin Mutasi berada pada poin ke 8 dengan kelemahan relatif ada pada poin ke 6 jumlah jawaban responden sebesar 483 dengan jumlah jawaban responden sebesar atau dengan nilai rata-rata 4.73 yang 448 atau nilai rata-rata 4.39 yang menyatakan sangat setuju dengan menyatakan "Saya merasa pekerjaan yang 
28 AGREGAT: Jurnal Ekonomi dan Bisnis

Vol. 1 No 1 Maret 2017

http://journal.uhamka.ac.id/index.php/agregat

DOI: $10.22236 /$ agregat_vol1/is1pp20-37

diberikan telah sesuai dengan kemampuan dari variabel Mutasi adalah 4.54.

saya”. Adapun untuk rata-rata keseluruhan

Tabel 2

Indikator Kinerja (Y)

\begin{tabular}{|l|l|l|l|}
\hline No. & Pernyataan & $\begin{array}{l}\text { Jumlah Jawaban } \\
\text { Responden }\end{array}$ & Rata-rata \\
\hline 1 & $\begin{array}{l}\text { Saya mampu menyelesaikan pekerjaan } \\
\text { tepat waktu. }\end{array}$ & 487 & 4.77 \\
\hline 2 & $\begin{array}{l}\text { Saya selalu teliti dalam menyelesaikan } \\
\text { pekerjaan. }\end{array}$ & 488 & 4.78 \\
\hline 3 & $\begin{array}{l}\text { Saya dapat menyelesaikan pekerjaan } \\
\text { melebihi target yang ditentukan. }\end{array}$ & 488 & 4.78 \\
\hline 4 & $\begin{array}{l}\text { Saya dapat mengerjakan tugas secara } \\
\text { efektif di dalam bekerja. }\end{array}$ & 489 & 4.79 \\
\hline 5 & $\begin{array}{l}\text { Saya mampu mentaati setiap peraturan } \\
\text { di perusahaan. }\end{array}$ & 480 & 4.70 \\
\hline 6 & $\begin{array}{l}\text { Saya dapat bekerja sama dengan sesama } \\
\text { karyawan dalam setiap pekerjaan. }\end{array}$ & 454 & 4.45 \\
\hline 7 & $\begin{array}{l}\text { Saya mampu membangun hubungan } \\
\text { kerja sama yang baik dengan atasan. }\end{array}$ & 438 & 4.29 \\
\hline 8 & $\begin{array}{l}\text { Saya masuk kerja sesuai dengan waktu } \\
\text { yang ditentukan. }\end{array}$ & 429 & 4.20 \\
\hline 9 & $\begin{array}{l}\text { Saya selalu meningkatkan kemampuan } \\
\text { dalam bekerja. }\end{array}$ & 460 & 4.50 \\
\hline 10 & $\begin{array}{l}\text { Saya bekerja dengan sungguh-sungguh } \\
\text { untuk mencapai tujuan. }\end{array}$ & 475 & 4.65 \\
\hline Rata-rata & & 2017 \\
\hline
\end{tabular}

Sumber: PT Kereta Api Indonesia (Persero) Daerah Operasi 1 Jakarta, 2017

Dari tabel 2 dapat dilihat poin tertinggi ada pada poin ke 8 dengan jumlah atau kekuatan relatif pada indikator jawaban responden sebesar 429 atau nilai Kinerja berada pada poin ke 4 dengan rata-rata 4.20 yang menyatakan "Saya jumlah jawaban responden sebesar 489 masuk kerja sesuai dengan waktu yang atau nilai rata-rata 4.79 yang menyatakan ditentukan”. Sedangkan untuk rata-rata sangat setuju dengan pernyataan "Saya keseluruhan dari variabel Kinerja adalah dapat mengerjakan tugas secara efektif di 4.59 . dalam bekerja”. Poin kelemahan relatif 
Tabel 3

Uji Validitas

\begin{tabular}{|c|c|c|c|c|}
\hline Variabel & Pernyataan & $\mathbf{R}_{\text {hitung }}$ & $\mathbf{R}_{\text {tabel }}$ & Keterangan \\
\hline Mutasi Karyawan & Butir 1 & 0.360 & 0.1946 & Valid \\
\hline & Butir 2 & 0.350 & 0.1946 & Valid \\
\hline & Butir 3 & 0.355 & 0.1946 & Valid \\
\hline & Butir 4 & 0.436 & 0.1946 & Valid \\
\hline & Butir 5 & 0.447 & 0.1946 & Valid \\
\hline & Butir 6 & 0.280 & 0.1946 & Valid \\
\hline & Butir 7 & 0.298 & 0.1946 & Valid \\
\hline & Butir 8 & 0.238 & 0.1946 & Valid \\
\hline & Butir 9 & 0.341 & 0.1946 & Valid \\
\hline & Butir 10 & 0.436 & 0.1946 & Valid \\
\hline Kinerja Karyawan & Butir 1 & 0.539 & 0.1946 & Valid \\
\hline & Butir 2 & 0.471 & 0.1946 & Valid \\
\hline & Butir 3 & 0.313 & 0.1946 & Valid \\
\hline & Butir 4 & 0.616 & 0.1946 & Valid \\
\hline & Butir 5 & 0.507 & 0.1946 & Valid \\
\hline & Butir 6 & 0.468 & 0.1946 & Valid \\
\hline & Butir 7 & 0.355 & 0.1946 & Valid \\
\hline & Butir 8 & 0.315 & 0.1946 & Valid \\
\hline & Butir 9 & 0.335 & 0.1946 & Valid \\
\hline & Butir 10 & 0.580 & 0.1946 & Valid \\
\hline
\end{tabular}

Sumber: Output SPSS 20.0

Dari hasil tabel uji validitas $\mathrm{R}$ tabel. Demikian indikator atau memperlihatkan nilai $\mathrm{R}$ hitung setiap kuesioner yang digunakan oleh masingindikator variabel Mutasi dan Kinerja masing variabel Mutasi dan Kinerja Karyawan lebih besar dibandingkan nilai dinyatakan valid untuk ukur varibel.

Tabel 4.

Hasil Uji Reliabilitas

\begin{tabular}{|l|l|l|l|}
\hline Variabel & Cronbach's alpha & Standar Reliabilitas & Keterangan \\
\hline Mutasi & 0.688 & 0,60 & Reliabel \\
\hline Kinerja & 0.763 & 0,60 & Reliabel \\
\hline
\end{tabular}

Sumber: Output SPSS 20.0

Nilai cronbach's alpha variabel Mutasi dapat disimpulkan bahwa indikator atau dan Kinerja lebih besar dari 0,60 sehingga kuesioner yang digunakan variabel Mutasi 
30 AGREGAT: Jurnal Ekonomi dan Bisnis

Vol. 1 No 1 Maret 2017

http://journal.uhamka.ac.id/index.php/agregat

DOI: $10.22236 /$ agregat_vol1/is1pp20-37

dan Kinerja, semua dinyatakan handal variabel.

atau dapat dipercaya sebagai alat ukur

Tabel 5

Hasil Statistik Deskriptif

Descriptive Statistics

\begin{tabular}{|c|c|c|c|c|c|}
\hline & $\mathrm{N}$ & Minimum & Maximum & Mean & Std. Deviation \\
\hline Mutasi & 102 & 38 & 50 & 45,47 & 3,127 \\
\hline $\begin{array}{l}\text { Kinerja } \\
\text { Karyawan } \\
\text { Valid } \\
\text { (listwise) }\end{array}$ & $N \mid \begin{array}{l}102 \\
102\end{array}$ & 38 & 50 & 45,96 & 3,057 \\
\hline
\end{tabular}

Sumber : Output SPSS 20.0

Hasil statistik deskriptif dari tabel sebesar 3.127.

diatas menunjukkan antara lain:

Variabel Kinerja Karyawan (Y) dengan

Variabel Mutasi (X) dengan jumlah jumlah sample (n) sebanyak 102 memiliki sampel (n) sebanyak 102 memiliki jawaban responden rata-rata (mean) jawaban responden rata-rata (mean) sebesar 45.96 dengan standar deviasi sebesar 45.47 dengan standar deviasi sebesar 3.057.

Tabel 6

Coefficients $^{\mathrm{a}}$

\section{Hasil Uji Koefisien Regresi Linier Sederhana}

\begin{tabular}{|c|c|c|c|c|c|c|}
\hline \multirow[b]{2}{*}{ Model } & & \multicolumn{2}{|c|}{$\begin{array}{l}\text { Unstandardized } \\
\text { Coefficients }\end{array}$} & \multirow{2}{*}{$\begin{array}{l}\text { Standardized } \\
\text { Coefficients } \\
\text { Beta } \\
\end{array}$} & \multirow[b]{2}{*}{$T$} & \multirow[b]{2}{*}{ Sig. } \\
\hline & & B & Std. Error & & & \\
\hline 1 & $\begin{array}{l}\text { (Constant } \\
\text { ) } \\
\text { Mutasi }\end{array}$ & $\begin{array}{l}22,250 \\
, 521\end{array}$ & $\begin{array}{l}3,769 \\
, 083\end{array}$ & ,533 & $\begin{array}{l}5,903 \\
6,305\end{array}$ & $\begin{array}{l}, 000 \\
, 000\end{array}$ \\
\hline
\end{tabular}

a. Dependent Variable: Kinerja Karyawan

Sumber: Output SPSS 20.0

Dari hasil perhitungan dengan 22.250 artinya jikamutasi diabaikan atau menggunakan SPSS diatas diperoleh nilai tidak dilakukan maka skor kinerja koefisien regresi $\mathrm{a}=22.250$ dan $\mathrm{b}=$ karyawan adalah 22.250. Sedangkan 0.521. Dari nilai koefisien regresi yang koefisien regresi sebesar 0.521 artinya jika diperoleh tersebut bila dimasukkan ke indikator mutasi meningkat naik satu poin dalam persamaan regresi adalah $\hat{\mathrm{Y}}=$ atau mutasi dilakukan satu kali maka $22.250+0.521 X$. Konstanta sebesar diperkirakan skor kinerja karyawan 
meningkat sebesar 0.521 poin pada tingkat signifikan $0.00<0.05$ artinya $\mathrm{H}_{0}$ konstanta 22.250. Dengan demikian ditolak dan $\mathrm{H}_{1}$ diterima dan pengaruh sebaiknya perusahaan harus melakukan antaramutasi terhadap kinerja karyawan mutasi karena dapat meningkatkan kinerja signifikan, yang berarti koefisien korelasi karyawan.

Uji parameter koefisien korelasi (Persero) Daerah Operasi 1 Jakarta. berdasarkan output SPSS menunjukkan

Tabel 7

Hasil Uji Normalitas

One-Sample Kolmogorov-Smirnov Test

\begin{tabular}{|ll|l|}
\hline & & $\begin{array}{l}\text { Unstandardized } \\
\text { Residual }\end{array}$ \\
\hline $\mathrm{N}$ & & 102 \\
Normal Parameters ${ }^{\mathrm{a}, \mathrm{b}}$ & Mean & 0000000 \\
& Std. Deviation & 2,58587091 \\
Most Extreme Differences & Absolute &, 061 \\
& Positive &, 052 \\
& Negative &,- 061 \\
Kolmogorov-Smirnov Z & &, 615 \\
Asymp. Sig. (2-tailed) & &, 844 \\
\hline
\end{tabular}

a. Test distribution is Normal.

b. Calculated from data.

Sumber: Output SPSS 20.0

Berdasarkan tabel 7 di atas, dapat $(0.844>0,05)$. Hasil ini juga didukung diketahui bahwa hasil pengolahan data dengan hasil analisis grafik normal p-plot. menunjukan besar nilai kolmogorov Pada prinsipnya normalitas dapat smirnov adalah 0.615 dan signifikansi dideteksi dengan melihat penyebaran data pada 0.844 maka disimpulkan data (titik) pada sumbu diagonal dari grafik terdistribusi secara normal karena nilai atau dengan melihat histogram dari Asymp.Sig. adalah 0.844 dan lebih besar residualnya. Hasil grafik normal p-plot daripada nilai signifikansi yaitu 0,05 pada penelitian ini seperti berikut:

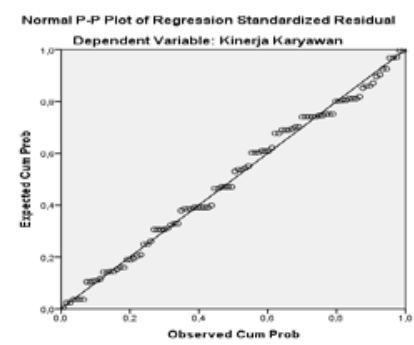

Gambar 1

Normal P-P Plot of Regression Standardized Residual 

AGREGAT: Jurnal Ekonomi dan Bisnis

Vol. 1, No. 1, Maret 2017

http://journal.uhamka.ac.id/index.php/agregat

p-ISSN: 2549-5658 e-ISSN: 2549-7243

DOI: $10.22236 /$ agregat_vol1/is1pp20-37

Hal 20-37

Berdasarkan gambar 1 di atas, pola arah garis diagonal sehingga dapat menunjukkan penyebaran titik-titik berada disimpulkan bahwa model regresi di sekitar garis diagonal dan mengikuti memenuhi asumsi normalitas.

\section{Uji Heteroskedastisitas \\ Gambar 2 \\ Scartterplot}

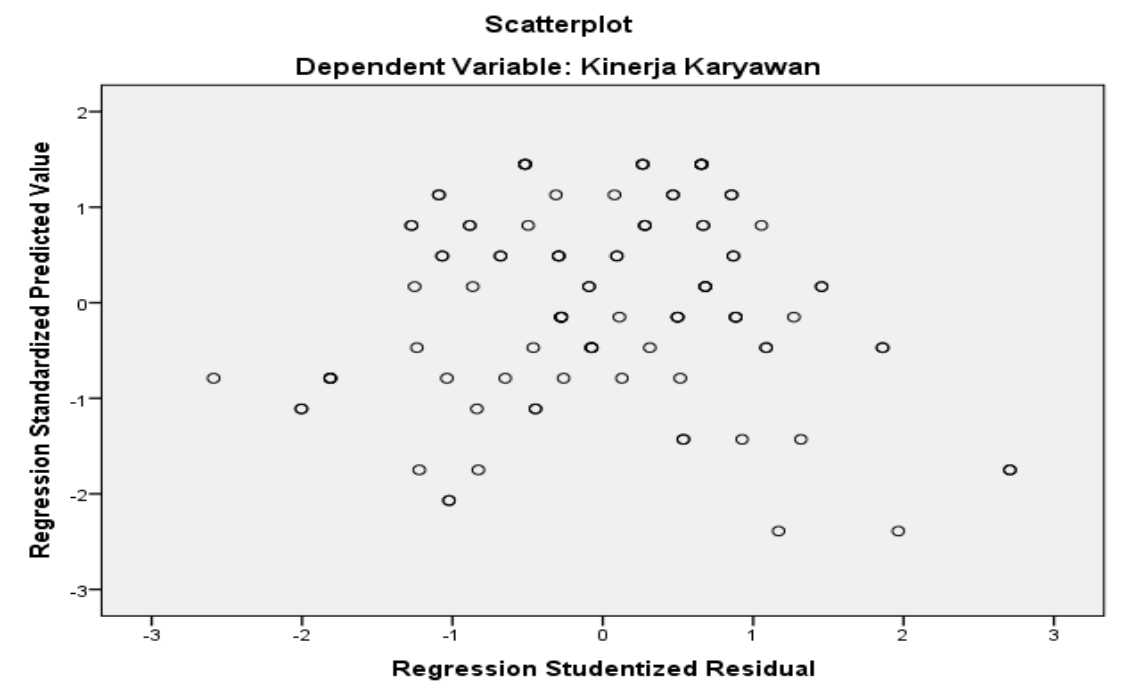

Berdasarkan grafik di atas dapat pada sumbu $Y$, sehingga model regresi diketahui bahwa variabel $\mathrm{X}$ dalam model layak dipakai untuk memprediksi merupakan homoskedastisitas karena pengaruh mutasi terhadap kinerja tidak ada pola yang jelas serta titik-titik karyawan.

menyebar di atas dan di bawah angka 0

\section{Uji Autokorelasi}

Uji Lagrange Multiplier. Uji bila sampel yang digunakan relatif besar autokorelasi dengan LM test terutama dan derajat autokorelasi lebih dari satu. digunakan untuk sample besar di atas 100 Uji LM akan menghasilkan statistik observasi. Uji ini memang lebih tepat Breusch-Godfrey, Imam Ghozali (2011: digunakan dibandingkan uji DW terutama 113). 
Tabel 8

Coefficients $^{\mathrm{a}}$

\section{Hasil Uji Lagrange Multiplier}

\begin{tabular}{|c|c|c|c|c|c|c|}
\hline \multirow{2}{*}{\multicolumn{2}{|c|}{ Model }} & \multicolumn{2}{|c|}{$\begin{array}{l}\text { Unstandardized } \\
\text { Coefficients }\end{array}$} & \multirow{2}{*}{\begin{tabular}{|l} 
Standardized \\
Coefficients \\
Beta
\end{tabular}} & \multirow[b]{2}{*}{$\mathrm{T}$} & \multirow[b]{2}{*}{ Sig. } \\
\hline & & B & Std. Error & & & \\
\hline 1 & (Constant) &,- 241 & 5,320 & &,- 045 &, 964 \\
\hline & Mutasi &,- 004 &, 084 &,- 004 &,- 042 &, 966 \\
\hline & LagRes1 &, 009 &, 084 &, 010 &, 103 & ,918 \\
\hline
\end{tabular}

a. Dependent Variable: Unstandardized Residual

Sumber: Ouput SPSS 20.0

Pada tabel 8 diatas menunjukan bahwa 0.05 pada nilai signifikansi. Artinya koefisien parameter legres 1 memberikan menunjukan indikasi tidak adanya probabilitas signifikan 0.918 atau diatas autokorelasi.

Tabel 9

Coefficients $^{\mathrm{a}}$

\section{Hasil Uji Koefisien Regresi (Uji t)}

\begin{tabular}{|ll|l|l|l|l|l|}
\hline \multirow{2}{*}{ Model } & & \multicolumn{2}{|l|}{$\begin{array}{l}\text { Unstandardized } \\
\text { Coefficients }\end{array}$} & $\begin{array}{l}\text { Standardized } \\
\text { Coefficients }\end{array}$ & & \multirow{2}{*}{ Sig. } \\
\cline { 2 - 6 } & & B & Std. Error & Beta & T & Seta \\
\hline 1 & (Constant) & 22,250 & 3,769 & & 5,903 &, 000 \\
& Mutasi &, 521 &, 083 &, 533 & 6,305 &, 000 \\
\hline
\end{tabular}

a. Dependent Variable: Kinerja Karyawan

Berdasarkan tabel 9 diatas dapat bahwa $\mathrm{H}_{1}$ diterima atau mutasi diketahui bahwa tingkat signifikansi berpengaruh signifikan terhadap kinerja sebesar 0,000 $<0,05$ dengan nilai $t_{\text {hitung }}=$ karyawan. Dengan demikian kebijakan 6.305 dan $t_{\text {tabel }}=1.66023$. Angka 1.66023 mutasi yang dilakukan perusahaan atau diperoleh dari $t_{\text {tabel }}$ dengan $\alpha=0,05$ dan PT Kereta Api Indonesia (Persero) Daerah derajat kebebasan (df) n-k-1 $=100$. Operasi 1 Jakarta dapat mempengaruhi Kesimpulannya $\quad t_{\text {hitung }}>t_{\text {tabel }}$ yaitu 6.305 kinerja dari setiap karyawan. $>1.66023$ sehingga dapat disimpulkan 
Tabel 10

Hasil Uji Simultan (Uji f)

ANOVA $^{\mathrm{a}}$

\begin{tabular}{|ll|l|l|l|l|l|}
\hline Model & & Sum of Squares & Df & Mean Square & F & Sig. \\
\hline 1 & Regression & 268,484 & 1 & 268,484 & 39,754 &, $000^{\mathrm{b}}$ \\
& Residual & 675,360 & 100 & 6,754 & & \\
& Total & 943,843 & 101 & & & \\
\hline
\end{tabular}

a. Dependent Variable: Kinerja Karyawan

b. Predictors: (Constant), Mutasi

Berdasarkan tabel 10 diatas dapat mutasi berpengaruh signifikan terhadap diketahui bahwa tingkat signifikansi kinerja karyawan. Dengan demikian sebesar 0,000 $<0,05$ dengan nilai $F_{\text {hitung }}=$ kebijakan mutasi yang dilakukan 39.754 dan $F_{\text {tabel }}=3,94$. Angka 3,94 perusahaan atau PT Kereta Api Indonesia diperoleh dari $F_{\text {tabel }}$ dengan $\alpha=0,05$ dan (Persero) Daerah Operasi 1 Jakarta dapat derajat kebebasan (df) n-k-1 = 100. Jika mempengaruhi kinerja dari setiap $F_{\text {hitung }}>F_{\text {tabel }}$ yaitu $39.754>3,94$ sehingga karyawan.

dapat disimpulkan bahwa $\mathrm{H}_{1}$ diterima atau

Tabel 11

Hasil Perhitungan Koefisien Korelasi dan Determinasi Model Summary ${ }^{\mathrm{b}}$

\begin{tabular}{|l|l|l|l|l|}
\hline Model & R & R Square & $\begin{array}{l}\text { Adjusted } \\
\text { Square }\end{array}$ & $\begin{array}{r}\text { R Std. Error of } \\
\text { the Estimate }\end{array}$ \\
\hline 1 & $.533^{\mathrm{a}}$ & .284 & .277 & 2.599 \\
\hline
\end{tabular}

a. Predictors: (Constant), Mutasi

b. Dependent Variable: Kinerja Karyawan Sumber: Output SPSS 20.0

Berdasarkan tabel 11 diatas, hubungan antaramutasi terhadap kinerja karyawan sedang karena koefisien korelasi sebesar 0.533. Nilai koefisien determinasi $r^{2}=$ 0.277 atau sebesar $27.7 \%$ artinya $27.7 \%$ variasi atau perubahan padakinerja karyawan merupakan kontribusi dari sedang, karena apabila dilakukan mutasi variabel mutasi, sementara $72.3 \%$ sisanya merupakan kontribusi pengaruh faktorfaktor lain seperti motivasi, pelatihan, kompetensi, produktivitas, dan sebagainya. Dengan demikian variabel mutasi memiliki kontribusi pengaruh yang 
maka kinerja akan berhubungan dan terpengaruhi sebesar 0.533 . 
36 AGREGAT: Jurnal Ekonomi dan Bisnis

Vol. 1 No 1 Maret 2017

http://journal.uhamka.ac.id/index.php/agregat

DOI: 10.22236/agregat_vol1/is1pp20-37

\section{SIMPULAN}

Berdasarkan hasil dan pembahasan dari bab sebelumnya, maka dapatditarik kesimpulan sebagai berikut: Faktor kekuatan relatifdari mutasi terletak pada pernyataan "Saya selalu memanfaatkan waktu bekerja dengan baik”, dengan nilai rata-rata 4.73. Sedangkan faktor kelemahan relatif darimutasi pada pernyataan "Saya merasa pekerjaan yang diberikan telah sesuai dengan kemampuan saya”, memiliki nilai rata-rata 4.39.Faktor kekuatan relatif dari kinerja karyawan terletak pada pernyataan "Saya dapat mengerjakan tugas secara efektif di dalam bekerja”, dengan nilai rata-rata 4.79. Sedangkan faktor kelemahan relatif dari kinerja karyawan pada pernyataan“Saya masuk kerja sesuai dengan waktu yang ditentukan”, memiliki nilai rata-rata 4.20.

Persamaan regresi yang diperoleh nilai koefisien regresi $\mathrm{a}=22.250$ dan $\mathrm{b}=$ 0.521. Dari nilai koefisien regresi yang diperoleh tersebut bila dimasukkan ke dalam persamaan regresi adalah $\hat{Y}=$ $22.250+0.521 \mathrm{X}$. Konstanta sebesar 22.250 artinya jikaMutasi diabaikan atau tidak dilakukan maka skor Kinerja Karyawanadalah 22.250. Sedangkan koefisien regresi sebesar 0.521artinya jika indikator Mutasi meningkat naik satu poin atau kebijakan mutasi dilakukan satu kali maka diperkirakan skor Kinerja Karyawan meningkat sebesar 0.521 poin pada konstanta22.250.

Berdasarkan hasil uji hipotesis, uji hasil parameter koefisien regresi tingkat signifikansi dapat diketahui bahwa tingkat signifikansi sebesar $0.000<0.05$ dengan nilai thitung $=6.305$ dan ttabel $=1.66023$. Angka 1.66023 diperoleh dari ttabel dengan $\alpha=0,05$ dan derajat kebebasan (df) $n-k-1=100$. Kesimpulannya thitung $>$ tabel yaitu $6.305>1.66023$ sehingga dapat disimpulkan bahwa $\mathrm{H} 1$ diterima atau Mutasi berpengaruh signifikan terhadap Kinerja Karyawan. Dengan demikian kebijakan mutasi yang dilakukan perusahaan atau PT Kereta Api Indonesia (Persero) Daerah Operasi 1 Jakarta dapat mempengaruhi kinerja dari setiap karyawan. Sedangkan berdasarkan tabel nilai koefisien determinasi r2 = 0.277atau sebesar $27.7 \%$ artinya $27.7 \%$ variasi atau perubahan padaKinerja Karyawan merupakan kontribusi dari variabel Mutasi, sementara $72.3 \%$ sisanya merupakan kontribusi pengaruh selain faktor mutasi dan kinerja karyawan. 
Hasil koefisien korelasi antara mutasi (X1), kinerja karyawan (Y) sebesar 0.533 artinya hubungan antaraMutasi terhadap Kinerja Karyawan sedang karena REFERENSI

Abadi, M.K.G. (2013). Effect of Job Mutation on Employee Performance in Irancell Company. Iran (diakses 29 Maret 2015).

Siswanto, B.S. (2003). Manajemen Tenaga Kerja Indonesia, edisi 2. Jakarta: PT. Bumi Aksara.

Bambang, W. (2013). Manajemen Sumber Daya Manusia. Bandung: PT Sulita

Bernardin, H. J. (2003). Human Resources Management: An Experiential Approach, 3rd edition, New York: McGrawHill/Irwin.

Dessler, G. (2011). Human Resource Management: Global Edition. Pearson Higher Education.

Follett, M.P. (1999). Visionary Leadership and Strategic Management. Women in Management Review, 14 (7). MCB University Press.

Gujarati, D.N. (2006). Ekonometrika Dasar. Jakarta: Penerbit Erlangga. Hasibuan, M. (2009). Manajemen Sumber Daya Manusia cetakan ketujuh. koefisien korelasi sebesar 0.533 . Korelasi positif menunjukan bahwa hubungan yang positif dan signifikan antara mutasi dan kinerja karyawan. Jakarta: PT Bumi Aksara.

Kadarisman. (2012). Manajemen Pengembangan Sumber Daya Manusia. Jakarta: Rajawali Press Mangkunegara, A.P. (2005). Sumber Daya Manusia Perusahaan. Bandung: Remaja Rosdakarya.

Mathis, R.L. \& Jackson, J.H. (2001). Manajemen Sumber Daya Manusia, Jakarta: Salemba Empat. Moeheriono. (2009). Pengkuran Kinerja Berbasis Kompetensi. Bogor: Ghalia Indonesia.

Robbins, S.P. \& Mary, C. (2010). Manajemen Jilid 1/Stephen $P$ Robbins dan Mary Coulter diterjemahkan oleh Bob Sabran, Wibi Hardani.-Ed.10, Cet.13-. Jakarta: Erlangga.

Rochaety, E. Tresnati, R. \& Madjid L. A. (2009). Metodologi Penelitian Bisnis: Dengan Aplikasi SPSS. Edisi revisi. Jakarta: Mitra Wacana Media.

Schermerhorn. (2005). Management 8th ed, John Wiley \& Sons, Inc, USA.

Siagian, S. (2008). Manajemen SDM. Cet 
38 AGREGAT: Jurnal Ekonomi dan Bisnis

Vol. 1 No 1 Maret 2017

http://journal.uhamka.ac.id/index.php/agregat

DOI: 10.22236/agregat_vol1/is1pp20-37

16. Jakarta: Bumi Aksara.

Sugiyono. (2008). Metode Penelitian

Kuantitatif Kualitatif dan R\&D. Bandung:

Penerbit Alfabeta.

(2012). Metode Penelitian

Administrasi. Cetakan Ke-20.

Bandung: Penerbit Alfabeta.

Veithzal, R. \& Ahmad, F.M.B. (2005).

Performance Appraisal Sistem

Yang Tepat Untuk Menilai Kinerja

Karyawan Dan Meningkatkan

Daya Saing Perusahaan. Jakarta.

PT Raja Grafindo Persada.

Wirawan. (2009). Evaluasi Kinerja

Sumber Daya Manusia. Jakarta:

Salemba Empat. 